\title{
Nigerian Rural Communities and Media Marginalization on COVID-19: Perspectives on Participatory Video
}

\author{
Osakue Stevenson Omoera ${ }^{1 *}$, Casmir E. Onyemuchara ${ }^{2}$, \\ Charles Okwuowulu ${ }^{3}$ \\ ${ }^{1}$ Department of English and Communication Studies \\ Faculty of Humanities, Federal University, Otuoke, Nigeria \\ Email: osakueso@fuotuoke.edu.ng \\ ${ }^{2,3}$ Theatre Arts Department \\ Alex Ekwueme Federal University, Ndufu Alike, Nigeria \\ Email: onyesoncasmir@gmail.com \\ Email: dr.charles.okwuowulu@gmail.com
}

\begin{abstract}
This article examined the impact of participatory video $(P V)$ technique in (re)educating rural dwellers on Corona virus (COVID-19) at Iva-Valley Forestry Hill Camp 1, Southeast Nigeria, with a view to generating data that could be tested or extrapolated elsewhere. It used historical-analytic, key informant interview (KII) and direct observation methods to argue that the COVID-19 pandemic/period has exposed weaknesses immanent in human institutions globally. One of such exposed interstitial gaps is the seeming weak media-link in the rural areas. This situation results from lack of electricity, non-access to reliable locally-generated news by resident community members and the lack of know-how to use mobile phones to generate media contents. Rural dwellers constitute 49.66 percent of the total Nigerian population (National Population Commission [NPC], 2018), yet media focus in Nigeria is mostly urban-driven. Having interacted and co-created a video script in Igbo with the community members through PV to determine the level of (mis)information that has permeated the community and (re)educated the rural dwellers on Corona virus and strategies to prevent its spread, the study canvassed the use of indigenous languages, diversification of media and PV techniques in the dissemination of credible information on COVID-19 in Nigeria, particularly at the grassroots.
\end{abstract}

Keywords: PV technique, Covid-19, social media, nigerian rural communities, media marginalization

Paper type: Research paper

*Corresponding author: osakueso@ fuotuoke.edu.ng

Submitted: 2020-07-27; Accepted: 2020-10-30; Published: 2020-10-30

Cite this document: Omoera, Osakue Stevenson, Casmir E. Onyemuchara, and Charles Okwuowulu. (2020). Nigerian Rural Communities and Media Marginalization on COVID-19: Perspectives on Participatory Video. The Journal of Society and Media, 4(2), 385-405. DOI: $10.26740 / j s m . v 4 n 2.385-405$ 


\section{INTRODUCTION}

This study examined the impact of participatory video (PV) technique, as a form of digital media production, in (re)educating rural dwellers on the new Corona virus (COVID-19), using Iva-Valley Forestry Hill Camp 1 in Enugu, Southeast Nigeria as a swivel of discussion and analysis. Before the advent of digital/social media, the arts and traditional media of radio and television served variously as watchdogs, sentinels, checks, socializers, mobilizers, connectors, entertainers, innovators, manipulators, advertisers, co-creators and educators in human societies (McLuhan 1965; Baran and Davis 1995; Dominick 1996; Adeseye and Ibagere 1999; Omoera 2006; Baran 2006; Omoera and Awosola 2008; Ekwuazi 2008; Awosola and Omoera 2008; Ibagere 2009; Ibagere 2010; Omoera 2010b; Omoera 2010c; Omoera 2010d; Gupta and Sinha 2010; Omoera, Awosola, Okhakhu, and Adesina 2010; Omoera 2010a; Omoera and Obekpa 2019).

In Africa, the media, whether traditional or digital (social media), like the arts, have been diachronically put to positive or negative use, depending on those at the helm of affairs, media professionals, civil society organizations or activists (Nyaole 2010; Ibagere and Omoera 2010; Omoera and Ibagere 2010; Okhakhu and Omoera 2010; Omoera, Awosola, Okhakhu and Eregare 2011; Okhakhu 2012; Omoera and Okhakhu 2013; Omoera 2014; Omoera and Ogah 2016). For instance, traditional and social media have played immense roles in escalating or de-escalating wars and conflicts in Africa. Conflicts resulting in wanton destruction of lives and properties and social dislocations such as the Liberian Civil War; the Boko Haram crises in parts of Nigeria, Cameroun, and Niger Republic; the conflagrations in the Congo; the Rwandan genocide and its remediation; Arab Spring uprisings that resulted in the removal of corrupt and dictatorial regimes in Egypt, Tunisia and Libya; the South-Sudan/Sudan political imbroglio and its resolution, the Ebola disease crisis and its attenuation in Sierra Leone and Nigeria, were to a large extent orchestrated by broadcast, print and social media.

Arguably, the media together with the people's arts have been deployed through several techniques for thought moulding, propaganda and war mongering, health awareness creation and social mobilization, political activism and crises resolution in Africa and elsewhere. The introduction of the global system for 
mobile communication (GSM) and the proliferation of smart phones have deepened the impact of arts on the society through the swift dissemination of information. This has equally affected media productions and the society in other diverse ways as many broadcast outfits have now introduced programmes such as eye-witness report, I-report, citizen journalism, among others, to generate news content for societal consumption. These programmes are aimed at having the populace report what is happening in their communities. Such innovative means have been adjudged as efficient because of their presumed raw and undiluted content in reporting (Monovich 2003).

In the same way, popular arts such as the theatre have in no small measure contributed to the dissemination of information and education of masses on important matters in contemporary society (Omoera 2010d). In fact, "theatre is increasingly becoming a predominant tool for sensitization and mobilization of local communities for economic, political and environmental development" (Inyang 2016). As a performative art in which human characters interact, and cocreate in the form of drama, dance, music, pantomime, opera, among others, the theatre animates the social, political, economic, religious and cultural priorities of the people. Prentki and Lacey assert that the theatre can break through language and cultural barriers and is an extremely useful communication tool (Prentki and Lacey 2004). They further posit that theatre does not only use words; it can also communicate effectively using mime, dance, images, local idioms and iconic cultural materials. This is ostensibly because theatre does not require much literacy skills or clever speaking to be effective. In fact, many local communities in Nigeria have engaged in community media or theatre activities through which they lent their voices in shaping government policies for the benefit of the generality of the people (Omoera and Obekpa 2020). Theatre, particularly in its applied form of theatre for development (TfD) engages the attention of people through a dramatic presentation of problems. It makes the audience see their problems in fresh and critical ways (Chukwukelue 2014). Apart from serving as entertainment, its focal trajectory has always been on information dissemination, mobilization, education and sensitization. To make the theatre achieve the abovementioned objectives, the people must be involved. Unearthing the people's challenges means engaging them to solve those identified issues in their 
communities. It is in this connection that TfD comes handy as a reliable tool in the re-storying or re-narrating of community challenges and setting pathways for development. Prior to digitalization, TfD was the most popular participatory theatre programme that was used to engage the masses at least in Africa; equipping them with information and strategies on how to address issues of botheration in their various localities.

Many theatre professionals and development agents now adopt digitalization/ICTs' enabled techniques such as PV to communicate, among other things, cultural identity and indigenousness, health and wellness and set development agendas for communities. White and Averson affirm that the video medium like film or TfD programme, when properly vested with seriousness of theme, could exert enormous persuasive power over an audience or even a community to achieve set deliverables (White and Averson 1969). In Video in the Villages (1989), The Spirit of TV (1990) and Meeting Ancestors: the Zo'e (1993), Vincent Carelli records the Waiapi Indian's documentation of themselves, for themselves on video. MacKenzie (MacKenzie 2000) informs that "Carelli, with the help of the Brazilian government, undertook the project in order to set up an archive of the traditions, cultures and images of Indian inhabitants of the Brazilian rain forests." MacKenzie further observes that the video narratives (visual texts) produced a strange effect within the Waiapi culture as the people began to mimic their imaginary view of their past traditions, in order to produce a 'true' document of their past even in their contemporary daily living to reassert their indigenousness.

At present, there are burgeoning misinformation, rumours, claims and misconceptions about social determinants of health $(\mathrm{SDH})$ in relation to conditions such as COVID-19 that circulate among Nigerians. Arguably, the media-marginalized rural dwellers in Nigeria are more susceptible to these kinds of misinformation, rumours and misconceptions, which could have adverse effects on their health and wellbeing. It is in this context that this article used participatory video (PV) technique to investigate the level of (mis)information on COVID-19 in Iva-Valley Forestry Hill Camp 1 in Enugu, Southeast Nigeria with a view to (re)educating the dwellers on how to avoid contracting it or preventing its spread. This study is an action research that employed the historical-analytic, 
key informant interview and direct observation methods to elicit information for analysis and discussion (marginalized 2020).

\section{METHOD}

Participatory Video as Technique in Community Media/Theatre. Gusztáv Nemes et al. (2007: 8-9) conceptualize participatory video (PV) as a "tool for the facilitation of individual and group learning and communication, wherein participants use the creation of video materials to share and make sense of their experiences and relationships." This implies that PV is a ICTs' enabled recording or documentary that involves the creation of awareness through community's participation in video production and broadcasting of communal problems or issues with a view to addressing them through communal efforts. Claudia Mitchell and Katie MacEntee (2016: 4) corroborate that PV is a participatory visual methodology in which a group or community creates their own film or video in order to voice their concerns or explore a particular issue. Accordingly, it involves a group of community members that create a video of their own in order to initiate an action towards solving their own problems.

PV can be a highly effective tool to engage and mobilize marginalized people to help them implement their own forms of sustainable development based on local needs (Lunch and Lunch 2006a:10). As a creative engagement or process of using digital media to lend a community's voice for social change, PV could be used to highlight "social determinants of health $(\mathrm{SDH})$ and health inequalities that are not directly within the health sector (Ataguba and Ataguba 2020), but critical to effective and risk communication for community's health and wellbeing. Ever since its conceptualization, studies on PV processes have been conducted in different parts of the world, including Nigeria. Its capacity to X-ray communal anxieties, fears, problems and aspirations has been proved to be a profitable means of proffering solutions to the collective problems of a particular community as it amplifies the hitherto muted community voices, such that government or those at the helm of affairs can understand a community's problem and possibly offer solutions to it.

Sánchez and Domínguez (David and Dominicus 2015) observe that in the Julián Andrés Espinosa's assessment of two PV experiences in Spain and 
Portugal, he considers the practice as a process of social intervention aiming to transform the participant community by promoting reflection about identity. Social transformation is achieved by the community in an act of emancipation linked to the use of the video technology which allows participants to create their own discourse. Other scholars such as Yang, Gusztáv, Guyana (Yang 2016; Gusztáv Nemes et al. 2007; Guyana and Berardi 2011; and Lunch and Nick 2006b) have similarly put PV into perspective. However, the crucial point in their various submissions is the adoption of hands-on video recording processes by community dwellers as a method towards steering the process of social change. While Gusztáv Nemes et al. (2007) emphasize the learning and communicative aspects to the community participants in a PV project, Nick Lunch and Chris Lunch (2006) see it as "a powerful means of documenting local people's experience and aspiration from their own perspective."

Wenger quoted in Sánchez and Domínguez (2015: 4) claims that in theorizing PV, the concept of "community of practice should at least have a domain (defined shared interest), a community (engagement in joint activities and discussion) and a practice (activities which require learning)" often interact to underscore the PV mythos. It is within this kind of arrangement that marginalized voices in a community are given opportunity to express themselves; the idea behind making a video can easily bring people together, explore issues and articulate a creative story from the people's perspective. The intention of PV is to provide a forum for deep discussion on collectively neglected social problems. Usually, the process is more important than the product as PV methodology breaks with the traditional filmmaking hierarchical relationship between active observer and passive subject. Lunch and Lunch (2006b) analysed Don Snowden's activities in Fogo Island, with small fishing communities off the eastern coast of Newfoundland and reports that as a result of watching each other's films, the different villagers on the island came to realise that they shared many of the same problems and that by working together they could solve some of them. The films were also shown to politicians who lived too far away and were too busy to actually visit the island. As a result of this dialogue, government policies and actions were changed. The techniques developed by Snowden became known as the Fogo process (Lunch and Lunch 2006b: 11). 
Omoera: Nigerian Rural Communities and

Media Marginalization on COVID-19:

Perspectives on Participatory Video

Indeed, PV has been adopted for different purposes such as data collection, reflexive filmmaking in the form of experiential filmmaking, collaborative community appraisal, needs assessment, awareness creation, health education, community mobilization and agit-prop. It is a subversion of what Jean Rouch describes as "a conversation of "us" with "us" about "them"; a conversation in which "them" is silenced; them always stand on the other side of the hill, naked and speechless, barely present in its absence (Garrette 2010). A kind of bottom-up approach to developing media stories that allows participants to "articulate, in their own words, what they wish to have conveyed and, ideally, take control of the production process from the researcher. It is an inversion of the top-down approach used by the 'big daddies' media to glare on communities in Africa. For Africans, the offshoot and deployment of participatory video (PV) is borne out of the quest to correct the misrepresentation of communities used by many big media corporations and give insights for community development.

As a development tool, PV technique has been used to address diverse issues of health, environment, agriculture, crises and risk communication. The Daughters of Niger Delta by Media Information and Narrative Development (MIND) is one of such efforts to address women health concerns and how environmental degradation affects sustainable health in the Niger-Delta region of Nigeria. A similar project was conducted on oil spillage in the area. The anxieties of the people of Niger Delta region constituted a subject of enquiry in the PV method used as reported by Lars Johansson (Johansson 2006). Johansson further noted the succinct way PV was used to spotlight the problem of farmers and fishermen whose livelihoods have been greatly threatened by the pollution of farmlands and seas by oil spillages in the region. Johansson submits that since the arrival of oil companies sixty (60) years ago, the Niger Delta region has become the 5th most polluted area in the world. This is as result of the over 4,000 spills that have spread crude oil throughout the swamps and over huge tracks of agricultural land as well as illegal gas flaring that produced a cocktail of toxic gases which in turns cause acid rain that destroyed crops (2006:4).

Many of the affected communities in the region are cut-off from the mainstream media, which are largely urban-based. They do not have access to social amenities such as electricity, potable water, accessible roads or reliable 
locally-generated news media. Hence, using the PV technique to document the problem in the Niger Delta communities where the inhabitants re-echoed the horrid effects of degradations on land and sea by oil exploration provided a visual context for dialogue with government and other critical stakeholders. This provoked serious discourse on how to chart ways of ameliorating the situation. The Ahmadu Bello University Department of Performing Arts in Zaria is also known to have extensively used PV to communicate sustainable health across northern Nigeria using local idiolects of the rural populace for facilitation and critical engagement.

Furthermore, Malawi is one of the nine African countries that is worst hit by HIV, thus AIDS is projected to reduce the agricultural workforce by $14 \%$ between 1985-2020 (Elliot 2006). To remediate the situation Elliot reports that PV was used to engage and encourage the citizens to get tested for HIV/AIDS, promote healthy lifestyle and rebuild self-esteem (2006). In Ghana, PV was adopted by Andrew Akrofi to demonstrate ways in which cocoa should be treated to avoid black pod disease which can result in crop losses of up to 90\% (Akrofi 2006). Chloe' Aicha Boro reviewed how Charming Chevrina employed the mascot of a puppet goat in a popular television programme TV Koodo in Burkina Faso which featured market prices for cattle and cereals as well as interviews with prominent figures in agricultural world (Vista 2011; Boro 2006) to encourage agricultural production. All of these go to show the potency of PV in addressing concerns of the populace, especially in marginalized communities where signs of modernity are farfetched.

In a precarious world, making videos to sensitize the populace about lifethreatening diseases or to expose harmful human or environmental practices that could endanger the lives of rural dwellers is a necessity for progress. When a group or community takes this step of documenting and reporting their challenges through video-making, it is taking action by creating awareness on its fears to the policymakers to mount interventionist programmes to redress the situation. The videos empower the people to ably tell their stories through the documentation of their own experiences, hopes and needs and according to their own perspective or standpoint. Only recently, the world was thrown into a quagmire after the World Health Organization (WHO) announced the emergence of a new dreaded virus named Corona virus. During a conference on Tuesday 11th February 2020, WHO 
Director General, Tedros Adhanom Ghebreyesus, announced the new name for the novel virus as COVID-19. As at January 21th 2020, WHO had reported that the total number of infected persons was 43,000 across the globe, but this has risen astronomically to about 8,385,440confirmed cases and 450,686confirmed deaths in 216countries, areas or territories (World Health Organization 2020). As a preventive measure through the creation of awareness to curb the spread of the dreaded virus, the participatory video (PV) technique was used to engage the populace in a rural community in Enugu, Southeast Nigeria.

\section{RESULT AND DISCUSSION}

Participatory Video Engagement at Iva-Valley Forestry Hill Camp 1. The Iva-Valley Forestry Hill Camp 1 is a rural settlement in Enugu State, Southeast Nigeria. The documentation here entails the PV research carried out by a team of researchers (the authors and some of their students) on COVID-19 among the elderly aged 60-90 years in the community. The first engagement of the participatory video (PV)was the internal process where the team met on Sunday 17th May, 2020, discussed and took the first step of facilitating the safety measures against the global pandemic ravaging the world. In the meeting, the team discussed the financial implications - transportation, video equipment, contact persons (who to meet first for permission), among others. It took cognizance of the fact that many of the residents are old, uneducated, and poor and that the signals from urban-based radio and television stations do not get to the area. Many members of the team were at Enugu following the lockdown that was necessitated by the COVID-19 pandemic, hence, Iva-Valley Forestry Hill Camp 1 was chosen. There was free intra-state movement in Enugu State and the team drove personal vehicles from the Enugu City to the site of study and vice versa throughout.

Infrastructure and services such as electricity, functional hospitals, access roads, potable water supply, conventional media such as radio and television stations, among others, are a rarity in this community. The indigenes rely heavily on face-to-face interactions, rumour-mills and occasional access to social media (when an individual is able to acquire a smart phone and buy data to browse the internet), which is prone to manipulation, miscommunication and disinformation 
in a post factual society (Hossová 2018). Therefore, the residents are virtually marginalized in terms of access to reliable information on health and social development generally. Emergent policies and advisories on crises and risk communication in regard to COVID-19 such as the practice of social distancing, avoiding large gathering, regular washing of hands, use of facemasks, and the use of other personal protective equipment (PPE) that are frequently disseminated on mainstream media to attenuate the COVID-19 infection, are observed more on the breach in Iva-Valley Forestry Hill Camp 1.

Participatory video (PV) which in a concrete sense is a digital form of TfD frowns at linguistic dexterity and openly welcomes the use of local languages, artforms and idioms. Hence, it was deemed wise to use Igbo Izugbe (central Igbo) as a form of communication for easy comprehension and all other engagements the team would have with the study population. On the type of equipment to be used, the team agreed to go for the use of smart phones which is not too common in the participatory video practice, but highly efficient and convenient. Its cost effectiveness and easy operation were topmost considerations. The team met with some elderly people consisting of both genders - female and male on Tuesday 19th May 2020. Before meeting the elders, the team first approached the community head of Iva-Valley Forestry Hill Camp 1 to obtain permission and which was granted. Each of the elderly persons represented eight households comprising about 48 families. During the visit, the team appraised the effects COVID-19 pandemic is having on many rural communities in Nigeria and shared diverse safety measures with them.

The next action was to produce the video for dialogue. The team had several interview sessions with a few elderly men who accepted to be interviewed and a majority of the elderly women who were very enthusiastic. Many of those interviewed on the novel Corona virus, showed some level of awareness with diverse stories of its origin. While some expressed fears about the economic, social, religious and cultural consequences of COVID-19 emergence, others were strident on government's insensitivity to the needs of the poor at the time of lockdown. The people complained that what they know about COVID-19 is what they get to hear from their children since electricity is nearly inaccessible in the area to even power and listen to broadcast news. Here are a few excerpts from some residents who interacted with the team. An elderly man speaks: 
Igbo

Ahubeghimudikaoriankaruruuwan'ile.

IweChinekedakwasirianyi.Anyiga'kpachara

'nyanauzonduanyi.

\section{English}

I have never experienced any disease that ravaged the world as this.The anger of the Lord has fallen on us. We all have to be careful with our ways. (Godwin Iteshi 2020, personal communication)

This view is buttressed by one of the elderly women interviewed who stated that she has heard about Corona Virus:"anunammaka coronamanaahughi $\mathrm{m}$ n'anyaonyeogburu" (I have heard of 'corona' but have not seen a dead victim). She reiterates the point: "Chinekenaekpeuwaikpe site nanrianriacorona"/God is judging the world through this means (corona). But she is not too bothered about the infectious disease. According to her,

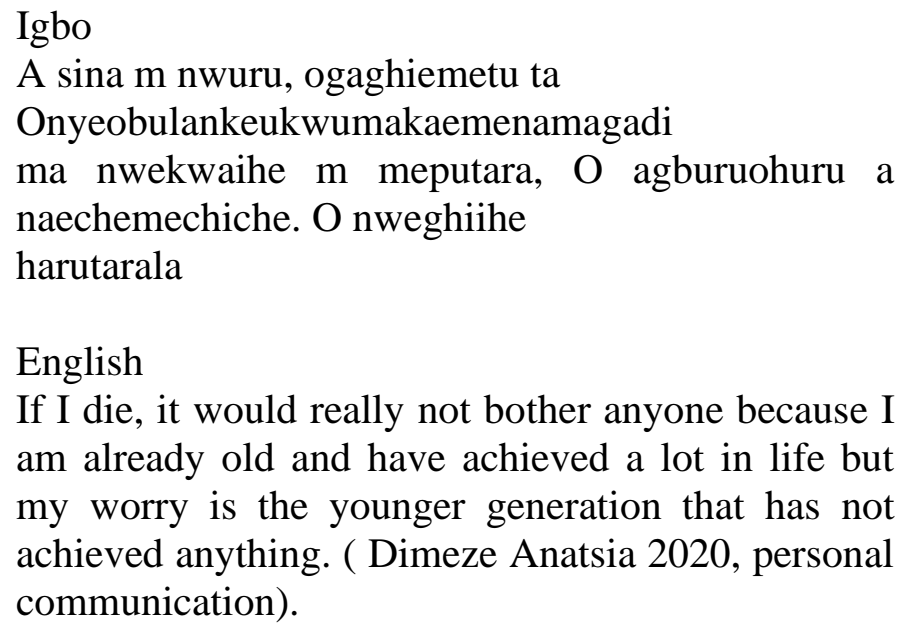

On the issue of government palliatives, some of them said they heard that they were giving the youths tricycles (keke) as a means of livelihood but never received any. Although some of them were sceptical about the video recording but seeing people from their community participating in the project, they gave in and accepted the team's recording. The PV engagement was handled by members of 
the community that collaborated with us. While the interview sessions were handled by the team, the engaged community members handled the recording with the mobile smart phones provided for them. The team streamed the video shots as recorded by the group and showed the interviewees' involvement in the process as captured real-time. The team members retired to Enugu City to rest and analyze the events of the day. A script for a drama skit was developed and read for the community members on Friday 22nd May, 2020. The interview guide was written in Igbo language and translated to English for analysis. The PV can be accessed at: https://youtu.be/JGDNPUpgr_0.

The team successfully drafted a short, direct and lesson-impact video script with the elderly people and read same before them to ensure that it captures all that they had shared. The video aimed at retracing the steps of the misinformed members of the community about the virus ravaging the world as well as engaging them to proffering home-made possible solutions. Excerpts of the play skit as developed

\section{Action}

Ebuka is seen clapping and jumping while singing an unpopular yet, popular(to him) song about coronavirus. He wears a face mask and approaching him is his wife Nkechi, and friend, Vivian. 
Vivian $\quad:$ (stops and tapsNkechi) Ebuka!! Ebuka O ogini di?

Nkechi : (slapping her hands together) Kedukaisi were egwu n' aguchimmadunti(rhetorical) keduihebunka? Mmaduagaghianurugiihe (They sigh).

Ebuka : (looking bewildered) Vivian, Nkechi (they answered him) Unuanubeghinkena-eme ugbua? (He shouts)

Chere go di! Keduebeununa-aga?

Nkechi : Hia! Anyina-agaahia nu.

Ebuka : Ununa-agaahia? Kedu nose mask unu?

Nkechi \& : Hia!! (Looking at each other and chorused) Nose Vivian maskkwa!

Ebuka : (exclaims loudly with his hands on his head) kedusanitiserunu? (Nkechi and Vivian stare at each other astonished). Unuenweghisanitiser, ипи a- $n$ ekiri m. N'ekiri m kaefimmiritirin'ahia.

Unuamaghiihena-emen'uwa. Coronavirus no n'uwaugbua(they sigh, turning their faces aside). Coronavirus ejidelandimbaJamini, gwepia ha, jidendiItali, suto ha, ji de ndi UK, gweriko ha $e$ gweri.Unu a siunuamaghiihenaeme.

Nkechi : Naninaikweteihegomentin'agwagigbasara coronavirus. Ihebuiwe Chinekedakwasirianyi (Ebuka exclaims loudly)

Ebuka : Iheununaekwunwereikeoburueziokwu, manaka $m$ gwakwaunu, unukwesiri I na-emeihegometikwuru. $O$ buruiweChineke, kaanyi me nkeanyijiburummadu.Coronavirus aabatalambaanyi Nigeria (Nkechi and Vivian look at each other)ihe a ana agwagi no zikwanaEnugwustati (they sigh, shifting). Ihe di mmakaanyimmeugbuabu ihe NCDC gwaraanyik'anyinaeme: di ka

Iyiri face mask ununaogeobula.

Ina akwochasi aka unu ma obujiri hand sanitisern'akpamgbe o bula.

Ijirinchakwo aka gimgbe o bulan'mmirinaagbaagba.

A no naebeigwemmaduno(social distancing).

Emetukwala aka gin a ihugi (anya, iminaonu)

Kwanyeukwaranamgbajinku aka gi ma obuijiriakwukwonkochapunwabeke (tissue paper). $\mathrm{Na}$ ihendiozobunke di nausoromgbochi Unughotaraiheanaekwu?

Nkechi : Anyinaaghota. Manakaanyi je siaahia nu.

Ebuka : Isi gini? Kaljesiaahia.Ngwa, je kaiwete face mask unuosiso.

(They rush to get their face masks and join Ebuka to dance his song to the amazement of the audience).

\section{End}


After reading the play excerpts to members of the community engaged in the project, the team and the community group agreed on the play title - Njigidesie Ike which means sustainability. The choice of this title is that since Corona virus is a global phenomenon, there is need to uphold the safety measures as prescribed by the World Health Organization (WHO) and the Nigerian Centre for Disease Control (NCDC). The performance generated a lot of feedback which was engaged by the team to record the level of impact the project had on the people. As an action research, the intention of this project is meant for a variety of purposes such as; Advocacy, Raising awareness, Sharing of knowledge, Evaluation and consultation among others.

The third phase of the project was the film editing stage. Here, the team collated all the shoots and sent to an editor who arranged it professionally to capture the real essence of the project. This included the detailed pictures of "Corona virus", an aerial view of rural communities, press briefing by the Nigerian minister of health and pictures of the COVID-19 pandemic with health workers across the globe. Lastly, the need for communication strategy for sharing of the videos was ignited. To do this, the team made use of YouTube, WhatsApp, and Facebook channels, etc., to share the film and generate comments that can help policymakers and the rural dwellers to prevent contracting COVID-19 or (un)consciously spreading it in their community.

This study has portrayed the experiences of socially excluded Nigerians even in the new normal period of COVID-19. Its findings indicate that many of the residents of Iva-Valley Forestry Hill Camp 1 had a lot of .misconceptions about the origin, spread and prevention strategies on COVID-19. This is likely so because they have no access to regular sources of reliable information on COVID19 and related health matters. The mainstream media of radio and television through which relevant government and nongovernmental agencies issued up-tothe-minute advisories on how to avoid being infected or prevent community transmission were virtually absent in the area. This is coupled with the fact that electricity is a rarity in the largely poor and far-flung community. Hence, the dwellers mostly depended on rumours and third-party opinions that might not be reliable. These issues constituted the crux of the experimental participatory videos that emanated from the researchers' engagement with people in the community under investigation. 
Having co-created video scripts and visuals with the people in Igbo on the need to use personal protective equipment (PPE) such as facemask, avoidance of large gatherings, frequent washing of hands, maintaining social distance and use of hand sanitizers as important elixirs of life in the fight against COVID-19, the rustics became amenable to change in terms of awareness on the social determinants of health they are expected to observe to forestall COVID infection or spread. In other words, the process of PV production helped the people to understand the diverse COVID-19 protocols and how to keep them. The inhabitants of Iva-Valley Forestry Hill Camp 1 were persuaded that apart from expecting interventions from government or NGOS, they were expected to first take responsibility for their safety and wellbeing. This makes the outcome of the study to be consistent with that of Gusztáv Nemes et al. (2007); Guyana and Berardi (2011); Lunch and Lunch (2006a; 2006b); Sánchez and Domínguez (2015); and Yang (2016) in which PV technique was used to engage rural folks and put issues that bothered them in perspective for possible remediation.

At any rate, the technique of participatory video (PV) for development and social change continues to gain popularity and success stories around the world. Separating PV from traditional documentaries is the absolute involvement with the community to create their own film, from the content to the actual filmmaking. It is an effective way to bring people together to discuss issues and voice concerns. The process is intended to be empowering at the local level which ideally will lead to the community solving their own problems, communicating their ideas to other communities or to decision makers to facilitate change (Doran 2008). It is on the basis of the foregoing that this study suggests the use of PV in communicating development, including health matters in other rural communities in Nigeria where the residents are media marginalized and largely cut-off from the mainstream of governance or government activities. It is germane to note too that with the increasing morbidity and mortality rate in different parts of the world occasioned by the COVID-10 pandemic, there is the need for relevant authorities to pay attention to those that are socially excluded by no fault of theirs, especially at the grassroots. 


\section{CONCLUSION}

The COVID-19 appears to be an issue that will be with humanity for a long time if the experiences of other pandemics such as cholera, polio, and Ebola that the world is still battling with are anything to go by. This is more so in Africa, particularly Nigeria where health facilities, medical supplies and personnel are in short supply and the media of radio and television are mainly urban based. The mainstream media channels beam messages at the urban populace to the marginalization of the rural dwellers that constitute a greater number of the Nigerian population but largely uneducated or uninformed about current issues including COVID-19. This study experimented successfully a participatory video (PV) programme on creating awareness on COVID-19 and strategies to cope or prevent contracting it among the elderly aged 60-90 at Iva-Valley Forestry Hill Camp 1 in Enugu in Southeast Nigeria. In spite of the initial hiccups, it was discovered that the PV activity helped to correct the misconceptions the rustics had about Corona virus. Therefore, this study canvasses the use of participatory video techniques/TfD to create awareness about COVID-19 and strategies to cope with it or prevent its spread in Nigerian rural communities. In doing this, it suggested that the federal government of Nigeria (FGN) should give palliatives in the form of face masks, hand sanitizers, etc., to rural dwellers across Nigeria to make them amenable to the Nigeria Centre for Disease Control (NCDC) rules on social/physical distancing, stay-at-home regimens, etc. Important, too, relevant government and nongovernmental organizations should encourage theatre artists, media sociologists and development communication experts in conjunction with targeted rural communities to create play lets, short video scripts on Corona virus to be performed by and for the rural dwellers in their homesteads to convince them on the existence of the virus and the need to prevent its spread.

\section{REFERENCES}

Adeseye, Femi and Elo Ibagere. 1999. Communication and man: A theoretical base for the student. Akure: Ola-Olu Enterprises

Akrofi, Andrews. 2006. "Ghanaian Cocoa Farmer Videos Tackle Pod Pest." FilmMaking Farmers: A Current Awareness Bulletin for ACP Agriculture 34(10). Retrieved June 252020 (http://ictupdate.cta.int) 
Ataguba, Ochega A. and John E. Ataguba. 2020. Social Determinants of Health: The Role of Effective Communication in the COVID-19 Pandemic in Developing Countries. Global Health Action 13(1). DOI: 10.1080/16549716.2020/1788263.

Awosola, Rasaq K. and Osakue S. Omoera. 2008. Child rights and the media: The Nigerian Experience. Studies on Home and Community Science 2(2): 125131. DOI: $\quad$ www.tandfonline.com/doi/abs/10.1080/09737189.20

Baran, Stanley J. 2006.Introduction to Mass Communication: Media Literacy and Culture. Boston: McGraw- Hill Books Company.

Baran, Stanley J. and D.K. Davis. 1995. Mass Communication Theory Foundations, Ferment and Future. California: Wadsworth Publishing Company.

Boro, Chloé Aicha. 2006. "Puppet Goat Newsreader Covers Food Security, Grain Prices." Film-Making Farmers: A Current Awareness Bulletin for ACP Agriculture 34(7). Retrieved June 252020 (http://ictupdate.cta.int).

Chukwukelue, Uzodinma U. 2014. "Theatre as Tool for Development in Nigeria." IOSR Journal of Humanities and Social Science (IOSR-JHSS) 19 (I): 3440 .

David, Montero Sánchez and Manuel Moreno Domínguez. 2015. Rethinking the Definition of Participatory Video at the Interface of Theory and Practice. Glocal Times 22/23: 1-15.

Dominick, Joseph R. 1996. The Dynamics of Mass Communication (5th ed.). New York: McGraw-Hill Books Company.

Doran, Adam. 2008. "Book Review - Insights into Participatory Videos - A Handbook for the Field by Nick Lunch and Chris Lunch. 2006: Insightshare." American Communication Journal 10(2). Summer.

Ekwuazi, Hyginus. 2008. "Development communication: Towards a Synthesis of Ideas." The Crab: Journal of Theatre and Media Arts 4: 203-216.

Elliot, Dominic 2006. "Everyone's a Teacher, Everyone's a Student." FilmMaking Farmers: A Current Awareness Bulletin for ACP Agriculture 34(7). Retrieved June 252020 (http://ictupdate.cta.int).

Garrette, Bradley, L. 2010. "Videographic Geographies: Using Digital Video for Geographic Research.” Retrieved February $18 \quad 2020$ (http://phg.sagepub.com/content/early/2018/12/0309132510388337).

Gusztáv, Nemes, Chris High, Nadine Shafer and Rick Goldsmith. 2007. "Using Participatory Video to Evaluate Community Development."Paper for Working Group 3.XXII European Congress of Rural Sociology.Wageningen: N.P. 
Guyana, Jayalaxshmi M. and Andrea Berardi. 2011. The Challenges and Opportunities of Participatory Video in Geographical Research: Exploring Collaboration with Indigenous Communities in the North Rupununi. Royal Geographical Society, with the Institute of British Geographers X: 1-7.doi: 10.1111/j.1475-4762.2011.01064.

Hossová, Monika. 2018. "Fake News and Disinformation: Phenomena of PostFactual Society."Media Literacy and Academic Research 1(1):27-35.

Ibagere, Elo. 2009. Social Development, Television and Politics in Nigeria. Ibadan: Kraft Books Limited.

Ibagere, Elo. 2010. Introduction to African Traditional Communication System. Abraka: Delta State University Printing Press.

Ibagere, Elo and Osakue S. Omoera. 2010. "The Democratization Process and the Nigerian Theatre Artiste."Studies of Tribes and Tribals 8 (2): 67-75. DOI: https://doi.org/10.1080/0972639X.2010.11886620

Inyang, Ekpe. 2016. "Community Theatre as Instrument for Community Sensitization and Mobilsation." TydskrifvirLetterkunde 53(1): 149 159. DOI: http://dx.doi.org/10.4314/tvl.v53i1.10.

Johansson, Lars. 2006. "Niger Delta Farmers Battle Oil Spills and Gas Flaring with Participatory Video, Mobile-to-Web Messaging and Online Video Sharing." Film-Making Farmers: A Current Awareness Bulletin for ACP Agriculture 34: 4-6. Retrieved June 252020 (http://ictupdate.cta.int).

MacKenzie, Scott. 2000. "Mimetic Nationhood: Ethnography and the National." Pp. 241-259 in Cinema and Nation, edited by Mette Hjort and Scott MacKenzie. London: Routledge.

Marginalized Ears. 2020. “A Participatory Video on COVID-19.” Retrieved June 252020 (https://youtu.be/JGDNPUpgr_0).

McLuhan, Marshall. 1965. Understanding the Media: The Extensions of Man. New York: McGraw- Hill Books Company.

Mitchell, Claudia and MacEntee, Katie. 2016. "Participatory Video: Taking a No Editing Required Approach.” International Institute for Qualitative Methodology (IIQM) Master Class. McGill: Participatory Cultures Lab.

Monovich, Lev. 2003. "New Media from Borges to HTML." Pp. 13-25 in The Introduction to the New Media Reader, edited by Noah Wardrip-Fruin, and Nick Montfort. Cambridge, MA: The MIT Press.

Lunch, Nick and Chris Lunch. 2006a. Insights into Participatory Video: A Handbook for the Field. Oxford: InsightShare. 
Lunch, Nick and Chris Lunch.2006b. "Participatory Video a Revolution in Communication for Development." Film-Making Farmers: A Current Awareness Bulletin for ACP Agriculture 34: 3. Retrieved June 252020 (http://ictupdate.cta.int).

Nyaole-Kowuo, R. 2010. Media's Role in the Society: Watchdog, is it? Markurdi Journal of Arts and Culture 8: 265-272.

Okhakhu, Marcel A. 2012. "The Use of Mobile Cinema in Promoting Health Issues in Nigeria." Pp. 13-22in The Anthropologist, Special Volume 9: Contemporary Discourses on Media and Theatre Arts Studies in Nigeria, edited by Hyginus O. Ekwuazi, Charles O. Aluede and Osakue S. Omoera. New Delhi: Kamla-Raj Enterprises.

Okhakhu, Marcel A. and Osakue S. Omoera. 2010. "Broadcasting and Society: The Question of Functionality in the Nigerian Mediascape."Journal of Black and African Civilization 4(1):77-86.

Omoera, Osakue S. 2006. "Community Radio in Africa: An Imperative for Grassroots Development." Iroro: A Journal of Arts 11 (1\&2): 256-263.

Omoera, Osakue S. 2010a. "Potentials of the Television in Reinventing the Nigerian Tourism Industry. "Ekpoma Journal of Theatre and Media Arts 3 (1\&2): 89-93.

Omoera, Osakue S. 2010b. "Broadcast Media in Family Planning in Rural Nigeria: The Ebelle Scenario. Journal of Communication 1 (2): 77-85. DOI: https://doi.org/10.1080/0976691X.2010.11884773

Omoera, Osakue S. 2010c. The Import of the Media in an Emerging Democracy: An Evaluation of the Nigerian Situation. Journal of Social Sciences 22 (1): 33-38. DOI: https://doi.org/10.1080/09718923.2010.11892781

Omoera, Osakue S. 2010d. "Theatre for Development in Rural Nigeria: The Andaha Community Experience." AMA: Journal of Theatre and Cultural Studies 5 (1):45-58. Omoera, Osakue S. 2014. "Towards Redefining the News Agenda in the Nigerian Media for National Development."Austral: Brazilian Journal of Strategy \& International Relations 3 (5):117-135.

Omoera, Osakue S. and Clement A. Ogah. 2016. "Boko Haram as A-gent Pro-voca-teur of Destruction and Destabilization in Nigeria: The Media's Check." Brazilian Journal of African Studies 1(1):67-84.

Omoera, Osakue S. and Elo Ibagere. 2010. "Revisiting Media Imperialism: A Review of the Nigerian Television Experience."The International Journal of Research and Review 5:1-18. 
Omoera, Osakue S. and Evelyn E. Obekpa. 2019. "Neo-Colonial Dependence and Dualistic Development Models: An Exploration of the Development Communication Trajectory in Nigeria." The Journal of Society and Media 3(2):178-194. DOI: 10.26740/jsm.v3n2.p178-194

Omoera, Osakue S and Evelyn E. Obekpa. 2020. "Home Grown School Feeding Programme: The Advocacy Visit of Civil Society Organizations to Traditional Institutions in Kaduna State, Northwest Nigeria." A Paper Presented at a Virtual Conference on "Sharing Black and African Creative Energy, Consolidating Africa's Heritage and Identity in the 21st Century" Organized by Centre for Black and African Arts and Civilization (CBAAC) in Conjunction with the University of Benin, Benin City in August, 2020.

Omoera, Osakue S. and Marcel A. Okhakhu. 2013. "Political Coverage in the Nigerian Broadcast Media: The Need for Professionalism." GANGA: Journal of Language and Literary Studies 5(1): 118-134.

Omoera, Osakue S. and Rasaq K. Awosola. 2008). "Child Abuse and Media: An Assessment of Oredo Local Government Area of Edo State Nigeria."Pakistan Journal of Social Science 5 (1): 128-133.

Omoera, Osakue S., Rasaq K. Awosola, Marcel A. Okhakhu, and Adekunle A. Adesina. 2010. "HIV/AIDS and the Broadcast Media in Urban Communities in Edo State, Nigeria."The International Journal of Research and Review 4:1-15.

Omoera, Osakue S., Rasaq K. Awosola, Marcel A. Okhakhu, and Emmanuel A. Eregare. 2011."Seeking Solutions: Of Radio/Television Advertisement and Patients/Non-Patients' Perception of Traditional Medicine in Edo State, Nigeria.'The International Journal of Research and Review 6 (1): 48-64.

Prentki, Tim and Lacey, Claire. 2004. "Using Theatre in Development." Footsteps: A Quarterly Newsletter Linking Development Workers around the World 58.

VISTA-Participatory Video and Social Skills for Training Disadvantaged Adults. 2011. Synthesis Report - The Use of the Participatory Video in Adult Education: Experiences in Europe. Retrieved June 192020 (https://www.montesca.eu/VISTA/wpcontent/uploads/2012/11/Annex16_VISTA_Synthesis-Report_Use-of-theParticipatory- Video-in-Adult-Education_-Experiences-in-Europe_.pdf).

White, D.M. and Averson, R. 1969. Sight, sound and society: motion pictures and television in America. Boston: Beacon Press. 
Omoera: Nigerian Rural Communities and Media Marginalization on COVID-19:

Perspectives on Participatory Video | 405

World Health Organization. 2020. "Corona virus Disease (COVID-19) Pandemic." Retrieved June $25 \quad 2020$ (https://www.who.int/emergencies/diseases/novel-coronavirus-2019).

Yang, K.H. 2016. "Participatory Video in Practice."Participatory Video in Adult Education, Springer Briefs in Education.DOI 10.1007/978-981-101050-7_2. 